This is the peer reviewed version of the following article: Seeney A, Pattison Z, Willby NJ, Boon PJ, Bull CD. Stream invertebrate diversity reduces with invasion of river banks by non-native plants. Freshwater Biology 2019;64:485-496, which has been published in final form at https://doi.org/10.1111/fwb.13236. This article may be used for non-commercial purposes in accordance with Wiley Terms and Conditions for self-archiving.

\title{
Stream invertebrate diversity reduces with invasion of river banks by non-native plants
}

Running head: Invertebrate response to invasive plants

Alex Seeney $^{1 *}$, Zarah Pattison $^{1}$, Nigel J. Willby ${ }^{1}$, Philip J. Boon ${ }^{2}$ and Colin D. Bull ${ }^{1}$

${ }^{1}$ Biological and Environmental Sciences, University of Stirling, Stirling, United Kingdom

${ }^{2}$ The Freshwater Biological Association, The Ferry Landing, Far Sawrey, Ambleside, Cumbria, LA22 OLP, United Kingdom

*Corresponding author; Email: alex.seeney@stir.ac.uk; Tel: (+44) 7817995515; Address: 11 Rowan Crescent, Menstrie, Clackmannanshire, FK117DS, United Kingdom

Keywords: diversity, Fallopia japonica, Impatiens glandulifera, invasive species, macroinvertebrates

\section{Summary}

1. Invasion of riparian zones by non-native plants is a global issue and commonly perceived as a challenge for river and fishery managers, but the type and extent of ecological changes induced by such invasions remain poorly understood. Established effects on sediment delivery, allochthonous inputs and channel shading could potentially alter aquatic macroinvertebrate assemblages, with implications for in-stream ecological quality.

2. We assessed responses in the diversity, quality and heterogeneity of stream macroinvertebrate communities to riparian invasion by non-native plants. Macroinvertebrates were collected from 24 sites on low order streams in central and southern Scotland during spring and autumn. The effect of invasive non-native plants (INNP) on macroinvertebrates was assessed relative to that of local physical and chemical factors.

3. INNP cover was associated with stronger effects than other factors on local diversity of macroinvertebrates (33\% reduction at the highest INNP cover) but also increased macroinvertebrate abundance across sites. Invaded sites were also associated with lower macroinvertebrate biomonitoring scores. Community composition differed between invaded and uninvaded sites in autumn, but not in spring. However, INNP influence on macroinvertebrate composition was generally secondary to that of physicochemical variables (e.g. channel shade, substrate diversity). 
4. We demonstrate that the influence of INNP extends beyond well-known impacts on plant communities to reductions mainly in stream macroinvertebrate diversity. Combined with the negative impact on pollutionsensitive macroinvertebrate taxa this raises concerns over the ecological health of streams with heavily invaded riparian zones. Our findings suggest that efforts to improve low order streams by actively managing severe riparian invasions are merited, but the size and uncertainty of the likely ecological gains must also be evaluated against the effort involved.

\section{Introduction}

Riparian zones are diverse, complex habitats that provide an ecologically important buffer between land and water, regulating the health and quality of the watercourses they border. The dynamic nature of riparian zones increases their susceptibility to invasion, particularly by non-native plants, which can spread quickly throughout catchments (Richardson et al., 2000) and are associated with negative ecosystem-wide impacts (Simberloff, 2015) that are repeated on a global scale. The impact of invasive non-native plants (INNP) has been demonstrated on native plant communities (Pysek et al., 2012; Pattison et al., 2017). Other studies suggest that invasive alien trees may alter the structure of secondary consumer assemblages (McInerney \& Rees, 2017) and promote long-term changes in macroinvertebrate community structure (Becker \& Robson, 2009; Roon et al., 2014). Currently, river and fisheries managers, local authorities and environmental protection agencies devote significant resources to managing riparian plant invasions, but without strong evidence of impact it is challenging to justify these resources or envisage the potential ecological gains arising from management.

Freshwater macroinvertebrates are excellent indicators of environmental conditions, as their presence and abundance reflect a variety of instream physical and chemical characteristics (Li et al., 2010). In recent years biomonitoring has expanded to include other anthropogenic stressors alongside organic pollution (Murphy et al., 2015) and likely impacts on ecosystem processes such as organic matter decomposition and secondary production (Usseglio-Polatera et al., 2000b; Bonada et al., 2006). Given these advances, there remains a pressing need to assess the importance of riparian INNP cover as a driver of aquatic macroinvertebrate community structure, relative to the suite of environmental variables already known to influence macroinvertebrates. The effects of riparian INNP cover are particularly relevant when considering the ecological status of water bodies as prescribed under the EC Water Framework Directive (WFD) (Council of the European Communities, 2000). The WFD prescribes that assessments of ecological status should reflect the ability of a water body to support various biota (e.g. benthic macroinvertebrates and flora) characteristic of undisturbed conditions. As such, assessments must take account of the presence of INNP and their outcomes may be 
influenced by the impacts of invasive non-native species more generally (Macneil et al., 2013; Mathers et al., 2016). Since European countries are required under the WFD to restore failing water bodies to good ecological status, the presence of INNP may carry significant management implications, depending on the risks posed (Cardoso, 2008).

Invasive plants such as Fallopia japonica (Japanese knotweed) and Impatiens glandulifera (Himalayan balsam) are now widely established on river banks across the northern hemisphere. They influence the aquatic environment via shading, lowering of water temperature, and by altering the quality, quantity and timing of terrestrial carbon input (Claeson et al., 2013). Rapid growth enables INNP to outcompete native plants, leading to the formation of dense monocultures. These may reduce the ability of riparian vegetation to filter contaminants (Duquette et al., 2016), whilst early winter dieback potentially exposes river banks to erosion by floods (Greenwood \& Kuhn, 2015). Disturbances to native riparian vegetation can also permeate aquatic food webs: riparian shading modulates water temperatures (Broadmeadow et al., 2011), which, together with changes to the nutritional quality of allochthonous leaf litter (Kuglerová et al., 2017), may affect the diversity and abundance of aquatic macroinvertebrates, thereby altering decomposition rates (Lagrue et al., 2011; Claeson et al., 2013). Additionally, clearing of INNP along rivers has recently been shown to promote some recovery of vulnerable stream macroinvertebrate taxa (Mcneish et al., 2015).

The aim of this study was to assess whether riparian INNP affect the structure and turnover of aquatic macroinvertebrate communities, using field surveys to isolate the magnitude and direction of any effect from those of other environmental variables driving aquatic macroinvertebrate community structure. We hypothesised that changes to riparian vegetation caused by INNP would affect the composition of aquatic macroinvertebrate communities through changes to allochthonous inputs and by modifying local environmental conditions. We predicted that aquatic macroinvertebrate communities at sites with higher INNP cover would exhibit reduced diversity as a result of these physical and chemical changes.

\section{Methods}

Study sites

Sites were located on six low $\left(1^{\text {st }}\right.$ to $\left.4^{\text {th }}\right)$ order streams (Strahler, 1957) in catchments across central and southern Scotland (Figure 1), providing a range of geographically and environmentally varied sampling locations. On each stream, a pair of control (uninvaded) sites were located upstream from a pair of invaded sites containing established stands of either F. japonica or I. glandulifera, the sites in each pair being separated by an average of 
$0.35 \mathrm{~km}$. There were 24 study sites in total (Table S1). Sites were limited by the size of INNP stands present, and as such were standardised to a $20 \mathrm{~m}$ length of channel. Invaded sites were chosen according to the criteria that INNP coverage should exceed $50 \%$ of the vegetation cover on at least one bank, their characteristics otherwise being similar to those of upstream uninvaded sites (Sax et al., 2005). INNP cover at a site often fell below this threshold when considering the total INNP cover across both banks. Both I. glandulifera and F. japonica were assessed collectively, the focus of the study being on overall effects of invasion-related disturbances rather than differences between similar INNP species. Distances between sites and the downstream main stem river varied from $0.2-8.7 \mathrm{~km}$, to fulfil the need to match physicochemical characteristics and ensure suitable riparian invasive cover.

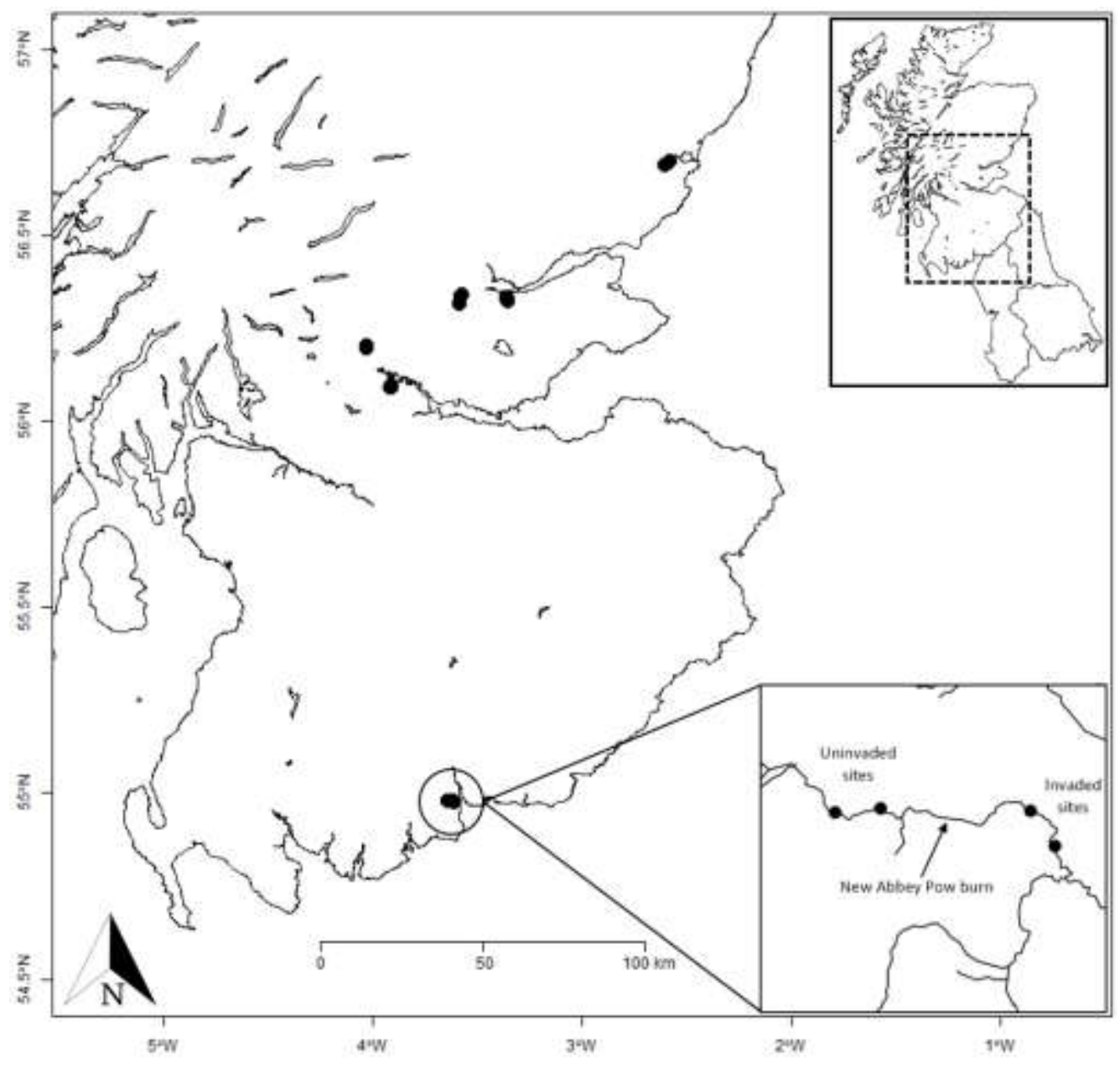

Figure 1. Map of study sites with example for the New Abbey Pow sites inset. Larger inset indicates general location of all study sites across central Scotland. 


\section{Macroinvertebrate sampling and processing}

Benthic invertebrates were collected by hand raking Surber samples (collecting area $0.3 \times 0.3 \mathrm{~m}$ ) for 30 seconds. To remove potential bias in the field (Hulme et al., 2013), sampling locations were randomly allocated prior to collection. Sites were sampled during spring and autumn 2015 to allow seasonal changes in macroinvertebrate composition to be assessed before and after the summer peak of INNP growth. Eight Surber samples were collected per site in each season to allow investigation of spatial heterogeneity in macroinvertebrate composition. Samples were preserved in the field with $70 \%$ industrial methylated spirits and subsequently sorted and identified to the lowest practicable taxonomic level, normally species (Table S3).

\section{Physico-chemical variables}

Environmental data were obtained through on-site measurements. Conductivity and $\mathrm{pH}$ were measured at each site in tandem with stream macroinvertebrate samples using a combimeter (HANNA instruments HI-98130 Pocket EC/TDS and $\mathrm{pH}$ Tester). Land use at both the $5 \mathrm{~m}$ and 50m scale was categorised based on visual assessment and supplemented by aerial photography accessed via Google Earth. The proportion of the channel that was shaded was estimated visually, and the total number of trees in the study reach exceeding $5 \mathrm{~m}$ in height was recorded as a proxy for the amount of channel shading caused specifically by riparian trees. Sites were surveyed using an electronic distance measuring instrument (Theomat Wild TC1000 electronic total station, Leica Geosystems Ltd, Milton Keynes, UK) to map the thalweg profile at each site and to derive an accurate measure of channel slope (Jones, 2010).

To investigate the diversity of the substrate, a Wolman count of 100 particles was made in summer using a gravelometer (Wolman, 1954), which categorises particle sizes according to their intermediate axis. Shannon's diversity index was then calculated for the substrate particle size composition at each site, treating each size class as a 'species', using the "diversity" function in the vegan (Oksanen et al., 2017) R package (R Core Team, 2017). Water velocity and depth were recorded for each specific Surber sample, using a flowmeter (SENSA RC2 Water Velocity Meter, Aqua-data Ltd, UK) and metre rule. To utilise these physical measurements in the analysis of macroinvertebrate species turnover, a Bray-Curtis (B-C) dissimilarity index was calculated using depth and velocity at the individual sample level. Used together, these variables enabled dissimilarity between sample locations to serve as a proxy for hydraulic habitat heterogeneity.

To quantify riparian INNP cover, vegetation surveys were conducted during August to coincide with peak growing season. Using three transects running perpendicular to the channel, three $1 \mathrm{~m}^{2}$ quadrats (where 
space permitted) were placed equidistantly on each transect between the foot and top of each bank, giving a total of 18 quadrats per site. The percentage cover of INNP in each quadrat was calculated and averaged over both banks to provide an estimate of invasive plant cover for the site.

\section{Macroinvertebrate metrics}

We focused on several metrics because of their relevance to national methods for assessing ecological status for WFD purposes (UKTAG, 2014). Macroinvertebrate community richness was expressed using the sample level alpha diversity based on the full complement of taxa recorded per Surber sample. The Whalley Hawkes Paisley Trigg (WHPT) index (Paisley et al., 2014), a reformulation of the widely used Biological Monitoring Working Party scoring system, was used to assess water quality. Values for this index range from 10 (most pollutionsensitive macroinvertebrates) to 1 (least sensitive). Due to strong variation in individual sample abundances and the representation of different taxa, the abundance-weighted WHPT score was used, whereby the index value for a sample is the log-abundance weighted average of the scores of the taxa present.

The proportion of sediment-sensitive invertebrates (PSI) (Extence et al., 2013) was calculated at each of the study sites in both spring at autumn, to assess whether taxa present at invaded sites indicated a greater degree of sediment loading.

Additionally, the Bray-Curtis dissimilarity index was used to express spatial heterogeneity in stream macroinvertebrate communities. A series of pairwise Bray-Curtis dissimilarities was generated for each season $\mathrm{x}$ site (comparing the $1^{\text {st }}$ sample to each of the rest, then the $2^{\text {nd }}$ to the rest, etc.). The average of these pairwise comparisons served as a measure of dissimilarity between a specific sample and the remaining samples from that site. Higher average values indicated greater spatial dispersion in composition between samples at a location on a given date. We also considered the total number of individuals per sample as a measure of macroinvertebrate abundance.

\section{Statistical analysis}

Four linear mixed effects models (LMMs) were used to investigate drivers of variation in the selected macroinvertebrate metrics (response variables: Simpson's diversity index, WHPT score, spatial dissimilarity and raw abundance). Predictors used in these models were channel shade, invasive cover, number of trees, channel slope, conductivity, habitat heterogeneity and substrate diversity. River identity was treated as a random effect.

To test for an effect of season, each model was run with season as a fixed effect. If this model output showed evidence of a significant seasonal effect $(\mathrm{p}<0.05)$ season was then included as an interaction term to 
determine whether predictors had seasonally-dependent effects. Prior to modelling, predictors were scaled to one standard deviation to allow their effects to be directly compared. All possible combinations of predictors were identified using the "dredge" function in MuMIn (Barton, 2017). Models were then ranked by their corrected Akaike information criterion (AICc) to account for small sample sizes. To identify the top set of models, a threshold of $\triangle \mathrm{AICc}<2$ was set (Burnham \& Anderson, 2002). From this top set (Table S2), a fully averaged model was chosen for interpretation of coefficients (Barton, 2017). To assess variation explained solely by the fixed effects, as well as variation explained by both the fixed and random effects together, both marginal and conditional $\mathrm{R}^{2}$ values are reported for each model (Nakagawa et al., 2013) (Table 1).

PSI scores were generated following the methodology described by Extence et al. (2013).

Macroinvertebrates were assigned a score based on their abundance at a site, and which related to their sensitivity to sediment. From these values, scores from each sensitivity group (ranging from highly sensitive to highly insensitive) were obtained for each site, which were used to assess the degree of pressure from fine sediment loading.

Species characteristics of invaded and uninvaded sites were identified using indicator species analysis (IndVal; Dufrêne \& Legendre, 1997) applied to species abundance data at the individual Surber sample level from the 12 invaded or uninvaded sites. The indicator value represents a product of the combined specificity and fidelity of aquatic macroinvertebrate species for invaded and uninvaded sites, after Dufrêne \& Legendre (1997). The index ranges from $0 \%$ (no presence in a survey group), to $100 \%$ (present in only one group, and in all samples within that group). The significance of these values was tested using a Monte Carlo randomisation procedure (Dufrêne \& Legendre, 1997).

Variation in macroinvertebrate species composition between invaded and uninvaded sites in spring and autumn samples was compared using non-metric multidimensional scaling (NMDS) (Kruskal \& Wish, 1978). To minimise the influence of highly abundant taxa, data were converted to presence/absence data (Borcard et al., 2011). To evaluate the contribution of individual environmental variables to overall macroinvertebrate community composition, we performed a redundancy analysis (RDA) by season, including INNP cover and all environmental attributes (channel shade, invasive cover, number of trees, channel slope, conductivity, habitat heterogeneity and substrate diversity) as explanatory variables. RDA was applied to Hellinger transformed macroinvertebrate species abundance data, and rare species were down-weighted (Borcard et al., 2011). The global model was reduced using forward selection based on AIC, to adhere to rules of model parsimony. We 
also performed a PERMANOVA to assess the relative contribution of individual environmental variables to variance in macroinvertebrate community composition in each season (Table S4 and Table S5).

All statistical analyses were conducted using R 3.4.3 (R Core Team, 2017), with the additional packages vegan (Oksanen et al., 2017), reshape2 (Wickham, 2007), biotic (Briers, 2016), labdsv (Roberts, 2016), lme4 (Bates et al., 2015), lmerTest (Kuznetsova et al., 2016), effects (Fox, 2003), MuMIn (Barton, 2017) and r2glmm (Jaeger, 2017).

\section{Results}

\begin{tabular}{|c|c|c|c|}
\hline Response & Model parameters & $\mathrm{R}^{2} \mathrm{~m}$ & $\mathrm{R}^{2} \mathrm{c}$ \\
\hline Simpson's diversity & $\begin{array}{l}\text { Channel slope }(1)+\text { depth*flow B-C }(1)+\text { invasive cover }(1)+\text { season } \\
(0.79)+\text { channel shade }(0.77)+\text { substrate diversity }(0.18)\end{array}$ & 0.14 & 0.22 \\
\hline WHPT & $\begin{array}{l}\text { Channel shade }(1)+\text { conductivity }(1)+\text { depth*flow B-C }(1)+\text { invasive } \\
\text { cover }(1)+\text { season }(1)+\text { substrate diversity }(1)+\mathrm{n}^{\circ} \text { trees }(1)+\text { channel } \\
\text { shade*season }(1)+\text { conductivity*season }(1)+\text { depth*flow B-C }(1)+ \\
\text { season*substrate diversity }(1)+\text { season* } n^{\circ} \text { trees }(0.74)+\text { invasive } \\
\text { cover*season }(0.31)\end{array}$ & 0.28 & 0.49 \\
\hline Abundance & $\begin{array}{l}\text { Channel shade }(1)+\text { invasive cover }(1)+\text { season }(0.56)+\text { conductivity } \\
(0.37)\end{array}$ & 0.07 & 0.39 \\
\hline Spatial dissimilarity & $\begin{array}{l}\text { Channel shade }(1)+\text { channel slope }(1)+\text { depth*flow B-C }(1)+\text { invasive } \\
\text { cover }(1)+\text { substrate diversity }(1)+\mathrm{n}^{\circ} \text { trees }(1)+\text { season }(0.78)+ \\
\text { conductivity }(0.48)\end{array}$ & 0.19 & 0.64 \\
\hline
\end{tabular}

Table 1 The best, fully-averaged models for models with $\Delta \mathrm{AICc}<2$. Relative variable importance is given in brackets, followed by marginal $\left(\mathrm{R}^{2} \mathrm{~m}\right)$ and conditional $\left(\mathrm{R}^{2} \mathrm{c}\right)$ values.

\section{Simpson's macroinvertebrate diversity}

Macroinvertebrate diversity was positively associated with channel slope and negatively associated with habitat heterogeneity (Figure 3a), indicating that fewer macroinvertebrate species were tolerant of increased spatial variation in water velocity and depth. Macroinvertebrate diversity was also negatively associated with invasive cover (Figures 2a and 3a), which had the greatest overall effect size (-0.13), with Simpson's macroinvertebrate diversity being on average $33 \%( \pm 5.6 \%)$ lower at $60 \%$ invasive cover (the maximum cover recorded in this study), compared to uninvaded sites. There was no evidence of any seasonal interaction. 
Macroinvertebrate WHPT score was positively associated with habitat heterogeneity and negatively associated with conductivity (Figure 3b) and invasive cover (Figures $2 b$ and $3 b)$. Conductivity (-0.47) and season (0.23) had the greatest overall effects on WHPT score. Macroinvertebrate WHPT score was on average approximately $5 \%( \pm 2.4 \%)$ lower at $60 \%$ invasive cover, compared to uninvaded sites. There was a positive interaction between season and conductivity, and season and channel shade. Greater conductivity and channel shade were associated with a higher WHPT score in spring compared to autumn, indicating the presence of more sensitive taxa at sites with these conditions in spring. There was a negative interaction between season and habitat heterogeneity, and season and substrate diversity. Greater habitat heterogeneity and substrate diversity were associated with a lower WHPT score in spring compared to autumn, perhaps in response to greater hydrological disturbance over the preceding winter.

The PSI scores ranged between 74.4 and 100, indicating that all study sites in both spring and autumn were classed as minimally sedimented or unsedimented, with a small number being classified as slightly sedimented (Extence et al., 2013). Additionally, there was no evidence of a trend in PSI scores associated with either invaded or uninvaded sites.

\section{Macroinvertebrate spatial dissimilarity}

Spatial dissimilarity in macroinvertebrate composition between samples at a site was positively associated with channel shade and habitat heterogeneity, indicating a more spatially diverse community at shaded and hydraulically diverse habitats. Spatial dissimilarity between samples at a site was negatively associated with number of trees, channel slope, substrate diversity (Figure 3c) and invasive cover (Figures 2c and 3c). Channel shade (0.04) and number of trees $(-0.03)$ had the greatest overall effects on macroinvertebrate spatial dissimilarity. The effect of invasive cover was marginal, on average reducing spatial dissimilarity by approximately $12 \%( \pm 3.4 \%)$ at $60 \%$ invasive cover, compared to uninvaded sites. There was no evidence of any seasonal interaction.

\section{Macroinvertebrate abundance}

Macroinvertebrate abundance was positively associated with invasive cover (Figures $2 \mathrm{~d}$ and $3 \mathrm{~d}$ ) and negatively associated with channel shade (Figure 3d), indicating a limiting effect of overhead shading on the availability of suitable habitat conditions for macroinvertebrates at our sites. At $60 \%$ invasive cover, sites on average contained33\% ( $\pm 11.0 \%)$ more macroinvertebrate individuals than uninvaded sites. No other variables were significant and there was no evidence of any seasonal interaction. 

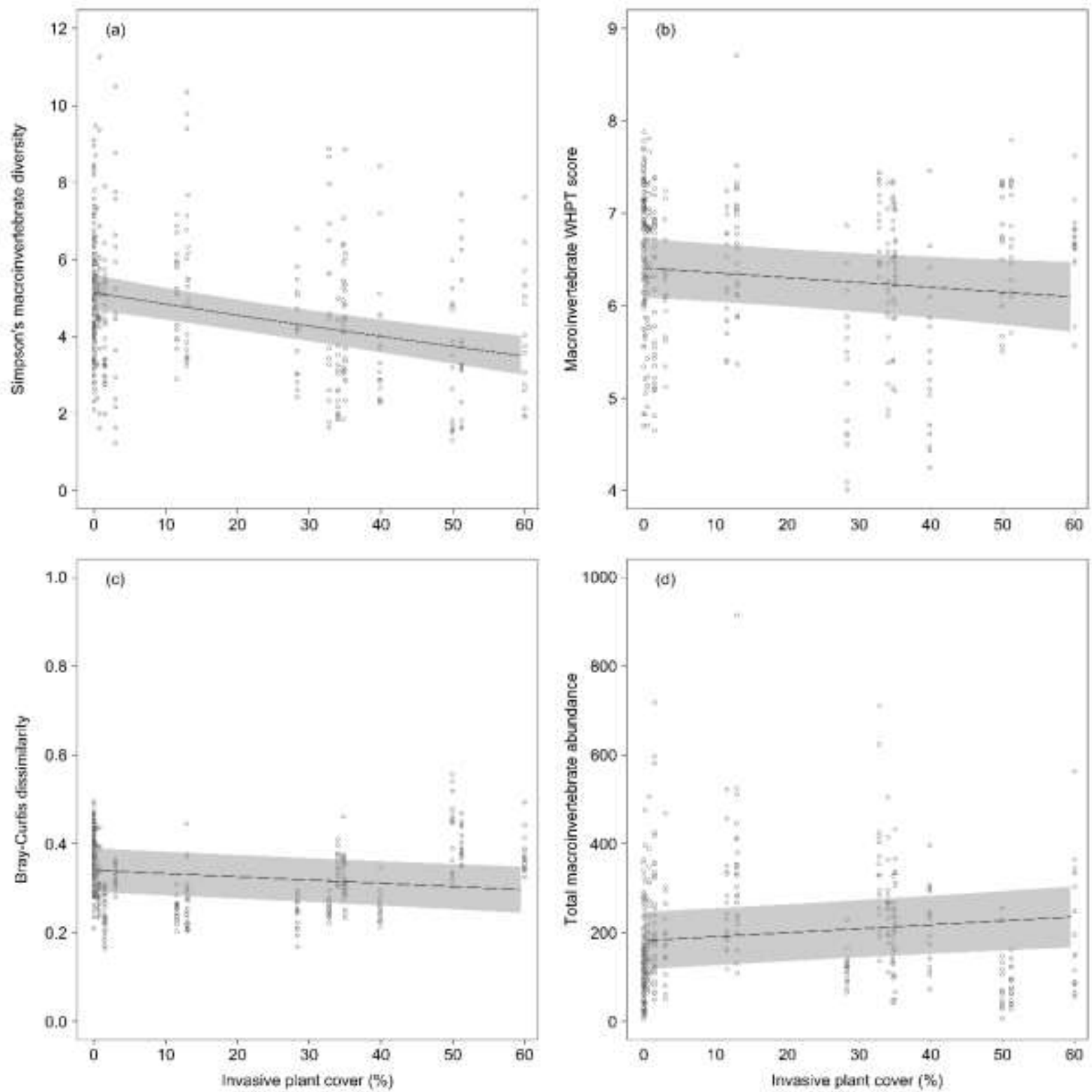

Figure 2. Full model predicted values (shaded polygon shows $\pm 95 \%$ confidence intervals) from the LMM analyses of (a) Simpson's macroinvertebrate diversity, (b) macroinvertebrate WHPT score, (c) spatial dissimilarity for individual Surber samples and (d) total macroinvertebrate abundance for individual Surber samples, all plotted against invasive cover. 

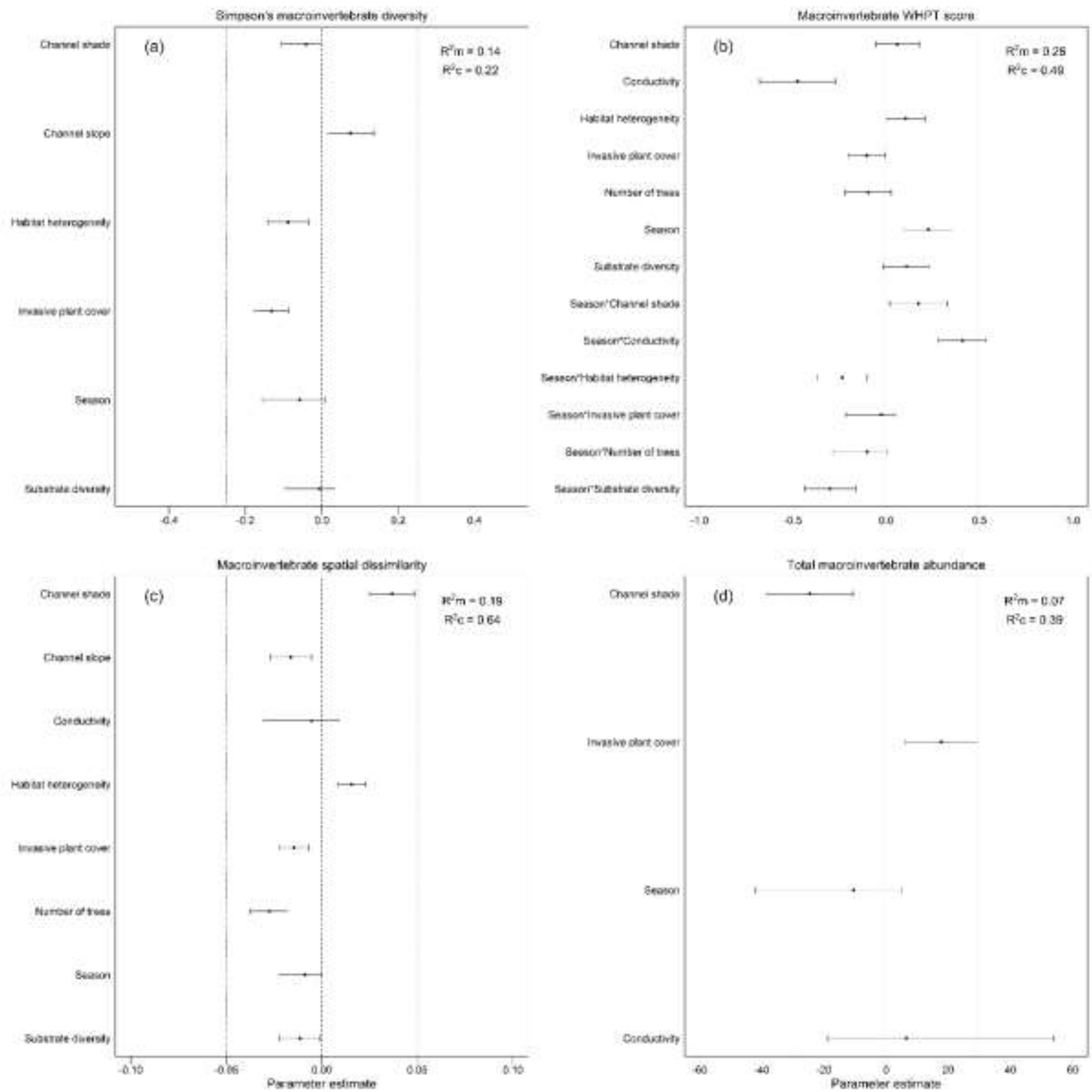

Figure 3. Full, model-averaged parameter estimates $\pm 95 \%$ confidence intervals. Modelled responses were (a)

Simpson's macroinvertebrate diversity, (b) macroinvertebrate WHPT score, (c) spatial dissimilarity for individual Surber samples and (d) total macroinvertebrate abundance. Marginal $\left(\mathrm{R}^{2} \mathrm{~m}\right)$ and conditional $\left(\mathrm{R}^{2} \mathrm{c}\right)$ values are given. 


\begin{tabular}{|c|c|c|c|c|}
\hline Site type & Species & Observed IV & $\begin{array}{l}\text { Biological/ecological } \\
\text { trait group }\end{array}$ & Functional feeding group \\
\hline \multirow[t]{7}{*}{ Invaded, spring } & Serratella ignita $* * *$ & 0.63 & $\mathrm{f} / \mathrm{C} 1$ & Deposit feeder \\
\hline & Gammaridae*** & 0.56 & $\mathrm{~b} 1 / \mathrm{C} 1$ & Shredder \\
\hline & Dicranota spp.*** & 0.50 & c1/D1 & Predator \\
\hline & Elminthidae*** & 0.37 & e3/B1 & Scraper \\
\hline & Drusus annulatus **** & 0.26 & f/A & Shredder \\
\hline & Ancylus fluviatilis* & 0.21 & $\mathrm{e} 2 / \mathrm{C} 1$ & Scraper \\
\hline & Ecclisopteryx guttulata* & 0.13 & f/A & Shredder \\
\hline \multirow{4}{*}{ Uninvaded, spring } & Baetis rhodani** & 0.47 & $\mathrm{e} 2 / \mathrm{C} 1$ & Scraper \\
\hline & Rhyacophila dorsalis* & 0.40 & $\mathrm{c} 1 / \mathrm{B} 2$ & Predator \\
\hline & Lepidostoma hirtum*** & 0.16 & $\mathrm{f} / \mathrm{C} 1$ & Grazer \\
\hline & Rhyacophila munda* & 0.06 & $\mathrm{c} 1 / \mathrm{B} 2$ & Predator \\
\hline \multirow[t]{9}{*}{ Invaded, autumn } & Dicranota spp.** $^{* *}$ & 0.55 & $\mathrm{c} 1 / \mathrm{D} 1$ & Predator \\
\hline & Gammaridae* & 0.46 & $\mathrm{~b} 1 / \mathrm{C} 1$ & Shredder \\
\hline & Silo pallipes $* * *$ & 0.44 & e2/B1 & Scraper \\
\hline & Limnius volckmari ${ }^{* * *}$ & 0.37 & e3/B1 & Scraper \\
\hline & Ecclisopteryx guttulata* & 0.36 & f/A & Shredder \\
\hline & Ancylus fluviatilis*** & 0.35 & $\mathrm{e} 2 / \mathrm{C} 1$ & Scraper \\
\hline & Lymnaea spp.* & 0.17 & $\mathrm{c} 2 / \mathrm{F} 3$ & Scraper \\
\hline & Baetis scambus* & 0.12 & $\mathrm{e} 2 / \mathrm{C} 1$ & Scraper \\
\hline & Paraleptophlebia spp.** & 0.12 & $\mathrm{f} / \mathrm{C} 1$ & Deposit feeder \\
\hline \multirow[t]{5}{*}{ Uninvaded, autumn } & Hydropsyche siltalai* & 0.36 & $\mathrm{e} 1 / \mathrm{C} 1$ & Filter feeder \\
\hline & Protonemura meyeri**** & 0.33 & f/A & Shredder \\
\hline & Amphinemura sulcicollis* & 0.21 & f/A & Shredder \\
\hline & Capnia bifrons ${ }^{* *}$ & 0.14 & e2/B2 & CPOM feeder \\
\hline & Philopotamus montanus** & 0.08 & e2/A & Filter feeder \\
\hline
\end{tabular}

Table 2 Significant indicator species for invaded and uninvaded sites. Observed IV shows the Indicator Value (a product of fidelity and specificity (Dufrêne $\&$ Legendre, 1997)) for each species $(0=$ no fidelity or specificity; 1 $=$ complete fidelity and specificity). Asterisks indicate the probability of that IV occurring by chance based on permutation tests $(* * *<0.001, * *<0.01, *<0.05)$. Biological and ecological group classifications are included after Usseglio-Polatera et al., 2000a , and broad functional feeding group classifications are included after Murphy \& Giller, 2000. 
A larger number of macroinvertebrate taxa were significantly associated with invaded sites compared to uninvaded sites in both spring and autumn (Table 2). In addition, marginally more macroinvertebrate taxa were significant indicators in autumn compared to spring. The strongest indicators of invaded sites in both spring and autumn were Gammaridae and Dicranota spp (Indicator values (IV) $=0.46-0.56$ ), with the addition of Serratella ignita $(\mathrm{IV}=0.63)$ in the spring. These taxa are indicative of a generalist preference for a range of substrates and slow to medium flow conditions (Usseglio-Polatera et al., 2000a), and suggest an in-stream habitat characterised by a moderate leaf litter input. Uninvaded sites were most strongly characterised by members of the Baetidae and Rhyacophilidae in spring (IV = 0.40-0.47), indicating a preference for more rheophilic and oligosaprobic conditions, and the presence of a suitable food source for predatory invertebrates. In autumn, uninvaded sites were most strongly characterised by Hydropsychidae and Nemouridae (IV $=0.33-0.36)$, again indicating greater flow and less organic matter entering the stream.

\section{Macroinvertebrate community composition}

Analysis of compositional data by NMDS showed a partition between invaded and uninvaded sites in autumn (Figure S2). No distinction could be found between invaded and uninvaded sites in spring (Figure S1).

Our RDA model for spring and autumn was a significant fit between the predictor variables and species abundance matrix, with conductivity and invasive cover being the only significant explanatory variables in both seasons. Consistent with the indicator species analysis, the autumn RDA triplot (Figure S3) showed clustering of taxa such as Gammaridae and Ancylus fluviatilis at higher invasive cover, while taxa such as Chloroperla tripunctata and Protonemura meyeri were associated with higher conductivity. Axes 1 and 2 explained $4 \%$ of the total variation. PERMANOVA indicated consistently high relative importance of conductivity and substrate diversity on variance in macroinvertebrate community composition, and these two variables were responsible for more than half of the variance explained by environmental variables in both spring and autumn (Table S4 and S5).

\section{Discussion}

\section{Effects on macroinvertebrate metrics}

Riparian INNP cover had the strongest association with Simpson's macroinvertebrate diversity compared to other measured environmental variables across both seasons, suggesting that high INNP cover in summer has a legacy effect on macroinvertebrate diversity which extends to the following spring. Additionally, INNP cover was positively associated with macroinvertebrate abundance and negatively associated with WHPT score, 
though the latter effect size was relatively minor in comparison to other environmental predictors (conductivity, habitat heterogeneity and substrate diversity). This suggests overall that invaded sites foster a greater abundance, but lower diversity of pollution-tolerant, low-scoring WHPT taxa. This suite of responses will be reflected in lower average ecological status, as inferred from invertebrates, at invaded stream sites. The indication that habitat quality for macroinvertebrates is lower at invaded sites is also consistent with the decreased spatial dissimilarity in composition between samples. The indicator species analysis adds further support for this, demonstrating that more taxa with lower WHPT scores showed fidelity to invaded sites (including Gammaridae, Dicranota spp. and Elmidae taxa), whilst more taxa with higher WHPT scores showed fidelity to uninvaded sites (including Rhyacophila spp., Lepidostoma hirtum, Protonemura meyeri and Amphinemura sulcicollis).

Reductions in riparian macroinvertebrate abundance, richness and biomass have previously been demonstrated in response to invasions by Fallopia species (Gerber et al., 2008), and these reductions may ultimately lead to changes in aquatic food web dynamics, as other species attempt to adjust to declines in more sensitive taxa (Covich et al., 1999). Additionally, the relationship between INNP cover and macroinvertebrate diversity may also reflect local changes in the chemical and physical properties of the leaf litter available to invertebrates, as well as variation in nutritional quality or palatability. Riparian INNP invasions may alter rates of litter decomposition by aquatic macroinvertebrates, but these changes appear to depend more on the type and quality of litter than invasive status per se (Kuglerová et al., 2017). Less palatable INNP litter or a reduction in the supply of preferred litter types might help to explain the observed reduction in macroinvertebrate diversity found at sites with higher INNP cover.

\section{Effects on macroinvertebrate community structure and heterogeneity}

Macroinvertebrate composition was most heterogeneous at sites with little or no invasive cover. Heavily invaded river banks can be left exposed to winter flooding due to rapid dieback of plants at the first frost, while fragile senesced material is easily dispersed by floods (Gowton et al., 2016). This exposure lowers bank stability (Gurnell, 2013) potentially increasing surface run-off and fine sediment entry and reducing water quality and primary production (Chapman et al., 2014). Fine sediment has well documented adverse effects on stream invertebrates (Jones et al., 2015), including reduced ability to utilise the hyporheic zone (Mathers et al., 2014), resulting in net loss of habitat. An increase in suspended sediment through the erosion of unprotected banks can adversely affect benthic invertebrates, increasing risk of predation (Bilotta \& Brazier, 2008), and homogenising sediments through fine sediment ingress (Burdon et al., 2013). However, our PSI analysis suggested that the 
benthic habitat at most sites in this study were minimally or only slightly sedimented, offering no evidence to link macroinvertebrate community response to INNP cover via channel sedimentation. Nevertheless, whilst the actual process of change remains undetermined, our results highlight a homogenising effect of riparian INNP cover on stream macroinvertebrate community composition, in agreement with Becker \& Robson (2009).

Invasive cover showed one of the strongest associations with macroinvertebrate spatial dissimilarity, but channel shade, habitat heterogeneity and number of trees also exerted strong effects. Although invasive cover appears to have some spatially homogenising effect on macroinvertebrates, it is clearly not the only environmental factor to do so. NMDS analysis showed evidence of differences in community composition between invaded and uninvaded sites in autumn, but not in spring. This is supported by the RDA analysis, which shows that community composition in the autumn is driven by invasive cover and conductivity. Macroinvertebrate taxa such as Gammaridae and Ancylus fluviatilis are associated with invaded sites, and are generally regarded as shredders and scrapers respectively (Murphy \& Giller, 2000). Taxa such as Lepidostoma hirtum are associated with uninvaded sites, and are regarded as grazers (Usseglio-Polatera et al., 2000a). These associations are in line with the indicator species analysis. This community variation in autumn is supported by the loss of several high-scoring WHPT taxa from Surber samples, including the heptagenid mayfly Ecdyonurus spp., the taeniopterygid stonefly Brachyptera risi and individuals from the philopotamid caddisfly Wormaldia spp.

The indicator species analysis did not provide support for reductions in availability or palatability of leaf litter at invaded sites, as both invaded and uninvaded sites harboured multiple taxa associated with plant matter and detritus (including Gammaridae, Baetis spp., Drusus annulatus and Ecclisopteryx guttulata). The indicator species analysis does perhaps suggest that shredders present at invaded sites in the spring were being partially replaced by scrapers in the autumn. This pattern was not found at uninvaded sites. Stream macroinvertebrates may be characterised by their feeding guild (Rawer-Jost et al., 2000) and community responses to alterations in the availability and quality of useable food sources may be an important, yet cryptic driver of change. We suggest that this apparent shift in feeding guild composition at invaded sites may be in response to the earlier dieback of INNP cover, reducing shading and allowing the re-establishment of biofilm (Sturt et al., 2011). However, it seems that overall, despite some clearly negative effects on macroinvertebrates, riparian INNP cover explains a relatively small amount of variation in macroinvertebrate community structure and is distinctly secondary to other environmental factors in this regard. 


\section{Management implications}

It is difficult to state with confidence that any management action will yield a defined result, taking into account site-specific properties, interactions between stressors (Vinebrooke et al., 2004; Jackson et al., 2016) speciesspecific responses (Altermatt et al., 2013) and the external factors that drive stochastic variation in ecosystems. Caution must therefore be exercised when using these findings to inform management policy, as the improvement in conditions through reducing riparian INNP cover at the local scale may deliver some ecological improvements, but may also yield a relatively low benefit-cost ratio if overwhelmed by effects of other anthropogenic stressors at coarser scales (Simberloff et al., 2013; Sundermann et al., 2013). Legacy effects of non-native invasions may also delay expected ecological responses (Cuddington, 2012; Corbin \& D'Antonio, 2017), and certain treatment or removal approaches may themselves adversely affect native biota (Flory \& Clay, 2009; Kettenring \& Adams, 2011). Nevertheless, this study provides evidence that the presence of extensive riparian INNP cover does indeed affect stream macroinvertebrate communities, and thereby offers conditional support for actively managing severe riparian invasions, and gauging expected responses.

\section{Conclusions}

We found that invasive non-native riparian plants have a unique and measurable effect on stream macroinvertebrates. Invasive riparian cover constrained and homogenised macroinvertebrate communities, demonstrated by significant negative associations with spatial dissimilarity, Simpson's macroinvertebrate diversity and WHPT score, and a positive association with abundance. Although we cannot exclude the possibility that some other unmeasured but causal pressure covaried closely with INNP cover, the effects we report are consistent with impacts reported for terrestrial INNP such as Rhododendron ponticum (Hladyz et al., 2011) and invasive species more generally (Roy et al., 2014; Gallardo et al., 2016). Furthermore, whilst our study demonstrates negative associations between INNP cover and macroinvertebrate communities, these effect sizes were often relatively small and as such may offer a low benefit-cost ratio as a result of any management efforts. Many other variables influenced macroinvertebrate communities, notably conductivity, channel slope, number of trees, channel shading and physical habitat heterogeneity, all of which themselves are prone to human modification. 


\section{Authors' Contributions}

All authors conceived the ideas and designed the methodology; AS, CB, NW and ZP collected the data; AS and ZP analysed the data; AS led the writing of the manuscript. All authors contributed critically to the drafts and gave final approval for publication.

\section{Acknowledgements}

We gratefully acknowledge financial support from Scottish Natural Heritage. Fergus McFarlane and Jack Shelton assisted with the collection and processing of macroinvertebrate samples. The authors declare they have no conflict of interest regarding this manuscript. 


\section{References}

Altermatt, F., Seymour, M., Martinez, N., \& Sadler, J. (2013). River network properties shape $\alpha$ diversity and community similarity patterns of aquatic insect communities across major drainage basins. Journal of Biogeography, 40, 2249-2260. doi:10.1111/jbi.12178

Barton, K. (2017). MuMIn: Multi-Model Inference. R package version 1.40.0. https://CRAN.Rproject.org/package=MuMIn.

Bates, D., Maechler, M., Bolker, B., \& Walker, S. (2015). Fitting Linear Mixed-Effects Models Using Ime4. Journal of Statistical Software, 67, 1-48. doi:10.18637/jss.v067.i01

Becker, A., \& Robson, B. J. (2009). Riverine macroinvertebrate assemblages up to 8 years after riparian restoration in a semi-rural catchment in Victoria, Australia. Marine and Freshwater Research, 60. doi:10.1071/mf08350

Bilotta, G. S., \& Brazier, R. E. (2008). Understanding the influence of suspended solids on water quality and aquatic biota. Water Res, 42, 2849-2861. doi:10.1016/j.watres.2008.03.018

Bonada, N., Prat, N., Resh, V. H., \& Statzner, B. (2006). Developments in aquatic insect biomonitoring: a comparative analysis of recent approaches. Annu Rev Entomol, 51, 495523. doi:10.1146/annurev.ento.51.110104.151124

Borcard, D., Gillet, F., \& Legendre, P. (2011). Numerical Ecology with R. New York: Springer.

Briers, R. (2016). biotic: Calculation of Freshwater Biotic Indices. R package version 0.1.2. https://github.com/robbriers/biotic.

Broadmeadow, S. B., Jones, J. G., Langford, T. E. L., Shaw, P. J., \& Nisbet, T. R. (2011). The influence of riparian shade on lowland stream water temperatures in southern England and their viability for brown trout. River Research and Applications, 27, 226-237. doi:10.1002/rra.1354

Burdon, F. J., McIntosh, A. R., \& Harding, J. S. (2013). Habitat loss drives threshold response of benthic invertebrate communities to deposited sediment in agricultural streams. Ecol Appl, 23, 1036-1047. doi:10.1890/12-1190.1

Burnham, K. K. P., \& Anderson, D. R. D. (2002). Model Selection and Multimodel Inference: A Practical Information-Theoretic Approach (2 ed.). London: Springer.

Cardoso, A. C. (2008). Incorporating invasive alien species into ecological assessment in the context of the Water Framework Directive. Aquatic Invasions, 3, 361-366. doi:10.3391/ai.2008.3.4.1

Chapman, J. M., Proulx, C. L., Veilleux, M. A., Levert, C., Bliss, S., Andre, M. E., . . Cooke, S. J. (2014). Clear as mud: a meta-analysis on the effects of sedimentation on freshwater fish and the effectiveness of sediment-control measures. Water Research, 56, 190-202. doi:10.1016/j.watres.2014.02.047

Claeson, S. M., LeRoy, C. J., Barry, J. R., \& Kuehn, K. A. (2013). Impacts of invasive riparian knotweed on litter decomposition, aquatic fungi, and macroinvertebrates. Biological Invasions, 16, 1531-1544. doi:10.1007/s10530-013-0589-6

Corbin, J. D., \& D'Antonio, C. M. (2017). Gone but not forgotten? Invasive plants' legacies on community and ecosystem properties. Invasive Plant Science and Management, 5, 117-124. doi:10.1614/ipsm-d-11-00005.1

Council of the European Communities. (2000). Directive 2000/60/EC of the European Parliament and of the Council of 23 October 2000

establishing a framework for Community action in the field of water policy. https://eurlex.europa.eu/legal-content/EN/TXT/?uri=celex:32000L0060. Official Journal of the European Communities, L327, 1-73

Covich, A. P., Palmer, M. A., \& Crowl, T. A. (1999). The Role of Benthic Invertebrate Species in Freshwater Ecosystems: Zoobenthic species influence energy flows and nutrient cycling. BioScience, 49, 119-127. doi:10.2307/1313537

Cuddington, K. (2012). Legacy Effects: The Persistent Impact of Ecological Interactions. Biological Theory, 6, 203-210. doi:10.1007/s13752-012-0027-5 
Dufrêne, M., \& Legendre, P. (1997). Species assemblages and indicator species: the need for a flexible asymmetrical approach. Ecological Monographs, 67, 345-366. doi:10.1890/00129615(1997)067[0345:SAAIST]2.0.CO;2

Duquette, M. C., Comperot, A., Hayes, L. F., Pagola, C., Belzile, F., Dube, J., \& Lavoie, C. (2016). From the Source to the Outlet: understanding the Distribution of Invasive Knotweeds along a North American River. River Research and Applications, 32, 958-966. doi:10.1002/rra.2914

Extence, C. A., Chadd, R. P., England, J., Dunbar, M. J., Wood, P. J., \& Taylor, E. D. (2013). The assessment of fine sediment accumulation in rivers using macro-invertebrate community response. River Research and Applications, 29, 17-55. doi:10.1002/rra.1569

Flory, S. L., \& Clay, K. (2009). Invasive plant removal method determines native plant community responses. Journal of Applied Ecology, 46, 434-442. doi:10.1111/j.1365-2664.2009.01610.x

Fox, J. (2003). Effect Displays in R for Generalised Linear Models. Journal of Statistical Software, 8. doi:10.18637/jss.v008.i15

Gallardo, B., Clavero, M., Sanchez, M. I., \& Vila, M. (2016). Global ecological impacts of invasive species in aquatic ecosystems. Glob Chang Biol, 22, 151-163. doi:10.1111/gcb.13004

Gerber, E., Krebs, C., Murrell, C., Moretti, M., Rocklin, R., \& Schaffner, U. (2008). Exotic invasive knotweeds (Fallopia spp.) negatively affect native plant and invertebrate assemblages in European riparian habitats. Biological Conservation, 141, 646-654. doi:10.1016/j.biocon.2007.12.009

Gowton, C., Budsock, A., \& Matlaga, D. (2016). Influence of disturbance on Japanese knotweed (Fallopia japonica) stem and rhizome fragment recruitment success within riparian forest understory. Natural Areas Journal, 36, 259-267. doi:Doi 10.3375/043.036.0306

Greenwood, P., \& Kuhn, N. J. (2015). The annual invasive plant, Impatiens glandulifera (Himalayan Balsam) as a trigger for high-magnitude soil erosion in temperate river systems. Geophysical Research Abstracts, 17

Gurnell, A. (2013). Plants as river system engineers. Earth Surface Processes and Landforms, 39, 4-25. doi:10.1002/esp.3397

Hladyz, S., Abjornsson, K., Giller, P. S., \& Woodward, G. (2011). Impacts of an aggressive riparian invader on community structure and ecosystem functioning in stream food webs. Journal of Applied Ecology, 48, 443-452. doi:10.1111/j.1365-2664.2010.01924.x

Hulme, P. E., Pysek, P., Jarosik, V., Pergl, J., Schaffner, U., \& Vila, M. (2013). Bias and error in understanding plant invasion impacts. Trends Ecol Evol, 28, 212-218. doi:10.1016/j.tree.2012.10.010

Jackson, M. C., Loewen, C. J., Vinebrooke, R. D., \& Chimimba, C. T. (2016). Net effects of multiple stressors in freshwater ecosystems: a meta-analysis. Glob Chang Biol, 22, 180-189. doi:10.1111/gcb.13028

Jaeger, B. (2017). r2glmm: Computes R Squared for Mixed (Multilevel) Models. R package version 0.1.2. https://CRAN.R-project.org/package=r2glmm.

Jones, G. F. (2010). Gravity-driven water flow in networks. Hoboken, New Jersey: John Wiley \& Sons, Inc.

Jones, I., Growns, I., Arnold, A., McCall, S., \& Bowes, M. (2015). The effects of increased flow and fine sediment on hyporheic invertebrates and nutrients in stream mesocosms. Freshwater Biology, 60, 813-826. doi:10.1111/fwb.12536

Kettenring, K. M., \& Adams, C. R. (2011). Lessons learned from invasive plant control experiments: a systematic review and meta-analysis. Journal of Applied Ecology, 48, 970-979. doi:10.1111/j.1365-2664.2011.01979.x

Kruskal, J. B., \& Wish, M. (1978). Multidimensional Scaling. In Quantitative Applications in the Social Sciences.

Kuglerová, L., García, L., Pardo, I., Mottiar, Y., \& Richardson, J. S. (2017). Does leaf litter from invasive plants contribute the same support of a stream ecosystem function as native vegetation? Ecosphere, 8, e01779. doi:10.1002/ecs2.1779 
Kuznetsova, A., Brockhoff, P. B., \& Christensen, R. H. B. (2016). ImerTest: Tests in Linear Mixed Effects Models. R package version 2.0-33. https://CRAN.R-project.org/package=ImerTest.

Lagrue, C., Kominoski, J. S., Danger, M., Baudoin, J. M., Lamothe, S., Lambrigot, D., \& Lecerf, A. (2011). Experimental shading alters leaf litter breakdown in streams of contrasting riparian canopy cover. Freshwater Biology, 56, 2059-2069. doi:10.1111/j.1365-2427.2011.02637.x

Li, L., Zheng, B. H., \& Liu, L. S. (2010). Biomonitoring and Bioindicators Used for River Ecosystems: Definitions, Approaches and Trends. International Conference on Ecological Informatics and Ecosystem Conservation (Iseis 2010), 2, 1510-1524. doi:10.1016/j.proenv.2010.10.164

Macneil, C., Boets, P., Lock, K., \& Goethals, P. L. M. (2013). Potential effects of the invasive 'killer shrimp' (Dikerogammarus villosus) on macroinvertebrate assemblages and biomonitoring indices. Freshwater Biology, 58, 171-182. doi:10.1111/fwb.12048

Mathers, K. L., Chadd, R. P., Extence, C. A., Rice, S. P., \& Wood, P. J. (2016). The implications of an invasive species on the reliability of macroinvertebrate biomonitoring tools used in freshwater ecological assessments. Ecological Indicators, 63, 23-28. doi:10.1016/j.ecolind.2015.11.051

Mathers, K. L., Millett, J., Robertson, A. L., Stubbington, R., \& Wood, P. J. (2014). Faunal response to benthic and hyporheic sedimentation varies with direction of vertical hydrological exchange. Freshwater Biology, 59, 2278-2289. doi:10.1111/fwb.12430

Mclnerney, P. J., \& Rees, G. N. (2017). Co-invasion hypothesis explains microbial community structure changes in upland streams affected by riparian invader. Freshwater Science, 36, 297-306. doi:10.1086/692068

Mcneish, R. E., Moore, E. M., Benbow, M. E., \& Mcewan, R. W. (2015). Removal of the invasive shrub, Lonicera maackii, from riparian forests influences headwater stream biota and ecosystem function. River Research and Applications, 31, 1131-1139. doi:10.1002/rra.2808

Murphy, J. F., \& Giller, P. S. (2000). Seasonal dynamics of macroinvertebrate assemblages in the benthos and associated with detritus packs in two low-order streams with different riparian vegetation. Freshwater Biology, 43, 617-631. doi:10.1046/j.1365-2427.2000.t01-1-00548.x

Murphy, J. F., Jones, J. I., Pretty, J. L., Duerdoth, C. P., Hawczak, A., Arnold, A., . . Collins, A. L. (2015). Development of a biotic index using stream macroinvertebrates to assess stress from deposited fine sediment. Freshwater Biology, 60, 2019-2036. doi:10.1111/fwb.12627

Nakagawa, S., Schielzeth, H., \& O'Hara, R. B. (2013). A general and simple method for obtaining R2 from generalized linear mixed-effects models. Methods in Ecology and Evolution, 4, 133-142. doi:10.1111/j.2041-210x.2012.00261.x

Oksanen, J., Blanchet, F. G., Friendly, M., Kindt, R., Legendre, P., McGlinn, D., . . Wagner, H. (2017). vegan: Community Ecology Package. R package version 2.4-4. https://CRAN.Rproject.org/package=vegan.

Paisley, M. F., Trigg, D. J., \& Walley, W. J. (2014). Revision of the Biological Monitoring Working Party (BMWP) score system: derivation of present-only and abundance-related scores from field data. River Research and Applications, 30, 887-904. doi:10.1002/rra.2686

Pattison, Z., Whytock, R., \& Willby, N. (2017). Invasion legacy effects versus sediment deposition as drivers of riparian vegetation. Biological Invasions, 20, 1189-1198. doi:10.1007/s10530-0171619-6

Pysek, P., Jarosik, V., Hulme, P. E., Pergl, J., Hejda, M., Schaffner, U., \& Vila, M. (2012). A global assessment of invasive plant impacts on resident species, communities and ecosystems: the interaction of impact measures, invading species' traits and environment. Global Change Biology, 18, 1725-1737. doi:10.1111/j.1365-2486.2011.02636.x

R Core Team. (2017). R: A language and environment for statistical computing. R Foundation for Statistical Computing, Vienna, Austria. URL https://www.R-project.org/.

Rawer-Jost, C., Bohmer, J., Blank, J., \& Rahmann, H. (2000). Macroinvertebrate functional feeding group methods in ecological assessment. Hydrobiologia, 422, 225-232.

doi:10.1023/A:1017078401734 
Richardson, D. M., Pysek, P., Rejmanek, M., Barbour, M. G., Panetta, F. D., \& West, C. J. (2000). Naturalization and Invasion of Alien Plants: Concepts and Definitions. Diversity and Distributions, 6, 93-107. doi:10.1046/j.1472-4642.2000.00083.x

Roberts, D. W. (2016). labdsv: Ordination and Multivariate Analysis for Ecology. R package version 1.8-0. https://CRAN.R-project.org/package=labdsv.

Roon, D. A., Wipfli, M. S., \& Wurtz, T. L. (2014). Effects of invasive European bird cherry (Prunus padus) on leaf litter processing by aquatic invertebrate shredder communities in urban Alaskan streams. Hydrobiologia, 736, 17-30. doi:10.1007/s10750-014-1881-x

Roy, H. E., Peyton, J., Aldridge, D. C., Bantock, T., Blackburn, T. M., Britton, R., ... Walker, K. J. (2014). Horizon scanning for invasive alien species with the potential to threaten biodiversity in Great Britain. Glob Chang Biol, 20, 3859-3871. doi:10.1111/gcb.12603

Sax, D. F., Kinlan, B. P., \& Smith, K. F. (2005). A conceptual framework for comparing species assemblages in native and exotic habitats. Oikos, 108, 457-464. doi:10.1111/j.00301299.2005.13402.x

Simberloff, D. (2015). Non-native invasive species and novel ecosystems. F1000Prime Rep, 7, 47. doi:10.12703/P7-47

Simberloff, D., Martin, J. L., Genovesi, P., Maris, V., Wardle, D. A., Aronson, J., ... Vila, M. (2013). Impacts of biological invasions: what's what and the way forward. Trends in Ecology \& Evolution, 28, 58-66. doi:10.1016/j.tree.2012.07.013

Strahler, A. N. (1957). Quantitative analysis of watershed geomorphology. Eos, Transactions American Geophysical Union, 38, 913-920. doi:10.1029/TR038i006p00913

Sturt, M. M., Jansen, M. A. K., \& Harrison, S. S. C. (2011). Invertebrate grazing and riparian shade as controllers of nuisance algae in a eutrophic river. Freshwater Biology, 56, 2580-2593. doi:10.1111/j.1365-2427.2011.02684.x

Sundermann, A., Gerhardt, M., Kappes, H., \& Haase, P. (2013). Stressor prioritisation in riverine ecosystems: Which environmental factors shape benthic invertebrate assemblage metrics? Ecological Indicators, 27, 83-96. doi:10.1016/j.ecolind.2012.12.003

UKTAG. (2014). UKTAG Guide to Invertebrates in Rivers. Invertebrates (General Degradation): Whalley, Hawkes, Paisley \& Trigg (WHPT) metric in River Invertebrate Classification Tool (RICT).

https://www.wfduk.org/sites/default/files/Media/Characterisation\%20of\%20the\%20water\% 20environment/Biological\%20Method\%20Statements/River\%20Invertebrates\%20WHPT\%20 UKTAG\%20Method\%20Statement.pdf.

Usseglio-Polatera, P., Bournaud, M., Richoux, P., \& Tachet, H. (2000a). Biological and ecological traits of benthic freshwater macroinvertebrates: relationships and definition of groups with similar traits. Freshwater Biology, 43, 175-205. doi:10.1046/j.1365-2427.2000.00535.x

Usseglio-Polatera, P., Bournaud, M., Richoux, P., \& Tachet, H. (2000b). Biomonitoring through biological traits of benthic macroinvertebrates: how to use species trait databases? Hydrobiologia, 422/423, 153-162. doi:10.1023/a:1017042921298

Vinebrooke, R. D., Cottingham, K. L., Norberg, J., Scheffer, M., Dodson, S. I., Maberly, S. C., \& Sommer, U. (2004). Impacts of multiple stressors on biodiversity and ecosystem functioning: the role of species co-tolerance. Oikos, 104, 451-457. doi:10.1111/j.0030-1299.2004.13255.x

Wickham, H. (2007). Reshaping Data with the reshape Package. Journal of Statistical Software, 21. doi:10.18637/jss.v021.i12

Wolman, M. G. (1954). A method of sampling coarse river-bed material. Transactions, American Geophysical Union, 35, 951-956. doi:10.1029/TR035i006p00951 
Table S1. Study site characteristics

\begin{tabular}{|c|c|c|c|c|c|c|c|c|c|}
\hline Catchment & $\begin{array}{l}\text { Catchment } \\
\text { area }\left(\mathbf{k m}^{2}\right)\end{array}$ & Study river & Site & Grid ref & $\begin{array}{c}\text { Stream } \\
\text { order }\end{array}$ & $\begin{array}{c}\text { Invasive } \\
\text { species }\end{array}$ & $\begin{array}{c}\text { Invasive } \\
\text { cover } \\
(\%)\end{array}$ & $\begin{array}{c}\text { Distance } \\
\text { from } \\
\text { source } \\
(\mathbf{k m}) \\
\end{array}$ & Dominant 50m land use \\
\hline \multirow{8}{*}{ Forth } & \multirow{8}{*}{1029} & \multirow{4}{*}{ Argaty } & $1-$ Native & NN 7398603332 & $1^{\mathrm{st}}$ & None & 0 & 2.5 & Mixed woodland/Improved grass \\
\hline & & & 2 - Native & NN 7396503257 & $1^{\mathrm{st}}$ & None & 0 & 2.4 & Improved grass \\
\hline & & & 3 - Invasive & NN 7397403201 & $1^{\mathrm{st}}$ & $F$. japonica & 60 & 2.3 & Mixed woodland/Improved grass \\
\hline & & & 4 - Invasive & NN 7412502505 & $1^{\mathrm{st}}$ & $F$. japonica & 35 & 1.5 & Mixed woodland \\
\hline & & \multirow{4}{*}{ Bannockburn } & 1 - Native & NS 8078090449 & $3^{\text {rd }}$ & None & 0 & 8.7 & Improved grass \\
\hline & & & 2 - Native & NS 8099390508 & $3^{\text {rd }}$ & None & 3 & 8.5 & Improved grass \\
\hline & & & 3 - Invasive & NS 8114190715 & $3^{\text {rd }}$ & $F$. japonica & 35 & 8.2 & Suburban \\
\hline & & & 4 - Invasive & NS 8124591140 & $3^{\text {rd }}$ & I. glandulifera & 34 & 7.8 & Suburban \\
\hline \multirow{8}{*}{ Tay } & \multirow{8}{*}{4990} & \multirow{4}{*}{ Dunning } & 1 - Native & NO 0205014918 & $2^{\text {nd }}$ & None & 2 & 3.3 & Tilled land \\
\hline & & & 2 - Native & NO 0203515075 & $2^{\text {nd }}$ & None & 1 & 3.1 & Tilled land \\
\hline & & & 3 - Invasive & NO 0255217372 & $3^{\text {rd }}$ & I. glandulifera & 13 & 0.5 & Tilled land \\
\hline & & & 4 - Invasive & NO 0258617625 & $3^{\text {rd }}$ & I. glandulifera & 33 & 0.2 & Tilled land \\
\hline & & \multirow{4}{*}{ Farg } & 1 - Native & NO 1628415553 & $2^{\text {nd }}$ & None & 0 & 3.4 & Improved grass \\
\hline & & & 2- Native & NO 1616815830 & $2^{\text {nd }}$ & None & 0 & 3.0 & Tilled land \\
\hline & & & $3-$ Invasive & NO 1597216240 & $2^{\text {nd }}$ & I. glandulifera & 13 & 2.6 & Scrub/Tall herbs/Tilled land \\
\hline & & & 4 - Invasive & NO 1577216504 & $2^{\text {nd }}$ & I. glandulifera & 12 & 2.2 & Suburban/Rough pasture \\
\hline \multirow{4}{*}{ Nith } & \multirow{4}{*}{1230} & \multirow{4}{*}{$\begin{array}{c}\text { New Abbey } \\
\text { Pow }\end{array}$} & 1 - Native & NX 9508666385 & $3^{\text {rd }}$ & None & 0 & 6.6 & Improved grass \\
\hline & & & 2 - Native & NX 9546166419 & $3^{\text {rd }}$ & None & 0 & 6.2 & Improved grass \\
\hline & & & 3 - Invasive & NX 9669966398 & $3^{\text {rd }}$ & $F$. japonica & 50 & 4.7 & Improved grass \\
\hline & & & 4 - Invasive & NX 9690166109 & $3^{\text {rd }}$ & $F$. japonica & 51 & 4.1 & Tilled land \\
\hline \multirow{4}{*}{ South Esk } & \multirow{4}{*}{3350} & \multirow{4}{*}{ Pow } & 1 - Native & NO 6288955530 & $3^{\text {rd }}$ & None & 0 & 4.3 & Tilled land \\
\hline & & & 2 - Native & NO 6302655535 & $3^{\text {rd }}$ & None & 2 & 4.1 & Tilled land \\
\hline & & & 3 - Invasive & NO 6430356472 & $4^{\text {th }}$ & I. glandulifera & 40 & 2.4 & Tilled land \\
\hline & & & 4 - Invasive & NO 6440456531 & $4^{\text {th }}$ & I. glandulifera & 28 & 2.2 & Tilled land \\
\hline
\end{tabular}


Table S2. Model selection summary for models with $\triangle \mathrm{AICc}<2$, for each response variable. Models are ranked in order of decreasing AICc weight $\left(\mathrm{W}_{\mathrm{i}}\right)$; models with a higher weighting carry more support. Log-likelihood ratios are also given

\begin{tabular}{|c|c|c|c|c|c|}
\hline Response & Model parameters & logLik & $\overline{\mathrm{AIC}_{\mathrm{c}}}$ & $\overline{\Delta_{\mathrm{i}}}$ & $\mathbf{W}_{\mathbf{i}}$ \\
\hline \multirow[t]{4}{*}{$\begin{array}{l}\text { Simpson's } \\
\text { diversity }\end{array}$} & $\begin{array}{l}\text { Channel shade }+ \text { channel slope }+ \text { depth*flow B-C }+ \\
\text { invasive cover }+ \text { season }\end{array}$ & -203.94 & 392.92 & 0.00 & 0.38 \\
\hline & $\begin{array}{l}\text { Channel slope }+ \text { depth*flow B-C }+ \text { invasive cover }+ \\
\text { season }\end{array}$ & -203.01 & 393.97 & 1.05 & 0.23 \\
\hline & $\begin{array}{l}\text { Channel shade }+ \text { channel slope }+ \text { depth } * \text { flow } B-C+ \\
\text { invasive cover }\end{array}$ & -203.24 & 394.07 & 1.15 & 0.21 \\
\hline & $\begin{array}{l}\text { Channel shade }+ \text { channel slope }+ \text { depth } * \text { flow B-C }+ \\
\text { invasive cover }+ \text { season }+ \text { substrate diversity }\end{array}$ & -206.20 & 394.42 & 1.50 & 0.18 \\
\hline \multirow[t]{3}{*}{ WHPT } & $\begin{array}{l}\text { Channel shade }+ \text { conductivity }+ \text { depth*flow B-C }+ \\
\text { invasive cover }+ \text { season }+ \text { substrate diversity }+\mathrm{n}^{0} \text { trees }+ \\
\text { channel shade* season }+ \text { conductivity*season }+ \text { depth*flow } \\
\text { B-C*season }+ \text { season*substrate diversity }+ \text { season*n }{ }^{*} \text { trees }\end{array}$ & -346.63 & 674.41 & 0.00 & 0.43 \\
\hline & $\begin{array}{l}\text { Channel shade }+ \text { conductivity }+ \text { depth*flow B-C }+ \\
\text { invasive cover }+ \text { season }+ \text { substrate diversity }+\mathrm{n}^{\circ} \text { trees }+ \\
\text { channel shade*season }+ \text { conductivity*season }+ \text { depth*flow } \\
\text { B-C }{ }^{*} \text { season }+ \text { invasive cover*season }+ \text { season* }{ }^{*} \text { substrate } \\
\text { diversity }+ \text { season } * n^{\circ} \text { trees }\end{array}$ & -347.67 & 675.06 & 0.65 & 0.31 \\
\hline & $\begin{array}{l}\text { Channel shade }+ \text { conductivity }+ \text { depth*flow B-C }+ \\
\text { invasive cover }+ \text { season }+ \text { substrate diversity }+\mathrm{n}^{0} \text { trees }+ \\
\text { channel shade* season }+ \text { conductivity*season }+ \text { depth*flow } \\
\text { B-C*season }+ \text { season*substrate diversity }\end{array}$ & -346.45 & 675.45 & 1.04 & 0.26 \\
\hline \multirow[t]{4}{*}{ Abundance } & Channel shade + invasive cover + season & -2286.02 & 4610.72 & 0.00 & 0.32 \\
\hline & Channel shade + invasive cover & -2290.37 & 4610.73 & 0.01 & 0.31 \\
\hline & Channel shade + conductivity + invasive cover + season & -2281.44 & 4611.24 & 0.53 & 0.24 \\
\hline & Channel shade + conductivity + invasive cover & -2286.53 & 4612.53 & 1.81 & 0.13 \\
\hline \multirow[t]{3}{*}{$\begin{array}{l}\text { Spatial } \\
\text { dissimilarity }\end{array}$} & $\begin{array}{l}\text { Channel shade }+ \text { channel slope }+ \text { depth*flow } \mathrm{B}-\mathrm{C}+ \\
\text { invasive cover }+ \text { season }+ \text { substrate diversity }+\mathrm{n}^{\circ} \text { trees }\end{array}$ & 532.47 & -1113.96 & 0.00 & 0.52 \\
\hline & $\begin{array}{l}\text { Channel shade }+ \text { channel slope }+ \text { conductivity }+ \\
\text { depth*flow B-C }+ \text { invasive cover }+ \text { season }+ \text { substrate } \\
\text { diversity }+n^{\circ} \text { trees }\end{array}$ & 529.02 & -1112.41 & 1.44 & 0.25 \\
\hline & $\begin{array}{l}\text { Channel shade }+ \text { channel slope }+ \text { conductivity }+ \\
\text { depth*flow B-C }+ \text { invasive cover }+ \text { substrate diversity }+n^{\circ} \\
\text { trees }\end{array}$ & 531.93 & -1112.14 & 1.72 & 0.22 \\
\hline
\end{tabular}


Table S3. Taxon list

Agapetus delicatulus

Drusus annulatus

Agapetus fuscipes

Dryopidae

Allogamus auricollis

Dytiscidae

Amphinemura sulcicollis

Ecclisopteryx guttulata

Ancylus fluviatilis

Annelida

Ecdyonurus dispar

Ecdyonurus insignis

Antocha spp.

Ecdyonurus torrentis

Aphelocheiridae

Asellus aquaticus

Athripsodes spp.

Baetis fuscatus

Baetis muticus

Baetis niger

Baetis rhodani

Baetis scambus

Baetis vernus

Bathyomphalus contortus

Beraeodes minutus

Berosus spp.

Brachyptera risi

Caenis rivulorum

Capnia atra

Capnia bifrons

Capnia vidua

Ceratopogoninae

Chaetopteryx villosa

Chironomidae

Chloroperla torrentium

Chloroperla tripunctata

Clinocerinae

Collembola

Cordulegaster boltonii

Corixidae

Curculionidae

Dasyhelea spp.

Dicranota spp.

Dinocras cephalotes

Diura bicaudata

Dixidae

Ecdyonurus venosus

Electrogena lateralis

Elmidae

Elminthidae

Elmis aenea

Elodes spp.

Empididae

Ephemera danica

Ephemerella notata

Ephydridae

Erpobdellidae

Esolus parallelepipedus

Forcipomyinae

Gammaridae

Glossiphoniidae

Glossosoma spp.

Goera pilosa

Gyraulus albus

Gyrinidae

Habrophlebia fusca

Halesus digitatus

Halesus radiatus

Hebridae

Helophorus spp.

Hydrachnidae

Hydraena spp.

Hydraenidae

Hydrophilidae

Hydroporinae

Hydropsyche angustipennis

Hydropsyche instabilis

Hydropsyche pellucidula 
Hydropsyche siltalai

Hydroptilidae

Isoperla grammatica

Lepidostoma hirtum

Leuctra fusca

Leuctra inermis

Leuctra hippopus/moselyi

Limnebius spp.

Limnius volckmari

Limnophora spp.

Limoniinae

Lymnaea spp.

Mesophylax impunctatus

Mesovelia furcata

Nemoura cambrica

Nemoura cinerea

Neureclipsis bimaculata

Noteridae

Odontocerum albicorne

Oligochaeta

Oulimnius spp.

Paraleptophlebia spp.

Pedicia spp.

Perlodes mortoni

Philopotamus montanus

Piscicola geometra

Planariidae

Planorbis corneus

Platambus spp.

Plectrocnemia conspersa

Polycelis spp.

Polycentropus flavomaculatus

Potamophylax latipennis

Proasellus meridianus

Protonemura meyeri

Protonemura praecox

Psychodidae

Psychomyia pusilla

Rhabdiopteryx acuminata

Rhithrogena semicolorata
Rhyacophila dorsalis

Rhyacophila munda

Rhyacophila obliterata

Scirtidae

Sericostoma personatum

Serratella ignita

Sialidae

Silo pallipes

Simuliidae

Siphlonuridae

Sphaeriidae

Taeniopterygidae

Theodoxus fluviatilis

Tipulidae

Velia spp.

Wormaldia spp. 
1 Table S4. Relative contribution of environmental predictors to variance in spring macroinvertebrate community 2 composition.

3

\begin{tabular}{ll}
\hline Environmental variable & Variance explained (\%) \\
\hline Conductivity & $10.7 * * *$ \\
Substrate diversity & $9.7 * * *$ \\
Depth*flow B-C & $2.8 * * *$ \\
Channel shade & $2.7 * * *$ \\
Invasive cover & $2.5 * * *$ \\
Number of trees & $2.1 * * *$ \\
Channel slope & $1.3 * *$ \\
\hline
\end{tabular}

4

5

6

7 Table S5. Relative contribution of environmental predictors to variance in autumn macroinvertebrate 8 community composition.

9

10

\begin{tabular}{ll}
\hline Environmental variable & Variance explained (\%) \\
\hline Conductivity & $10.1 * * *$ \\
Depth*flow B-C & $8.7 * * *$ \\
Substrate diversity & $5.0 * * *$ \\
Channel shade & $3.1 * * *$ \\
Invasive cover & $2.7 * * *$ \\
Number of trees & $1.8 * * *$ \\
Channel slope & $1.3 * * *$ \\
\hline
\end{tabular}


11 Figure S1. Non-metric multidimensional scaling ordination (NMDS) plot of macroinvertebrate species

12 composition, comparing invaded (red polygon) and uninvaded (blue polygon) sites in spring across 24 riparian 13 sites (stress $=0.22)$

14

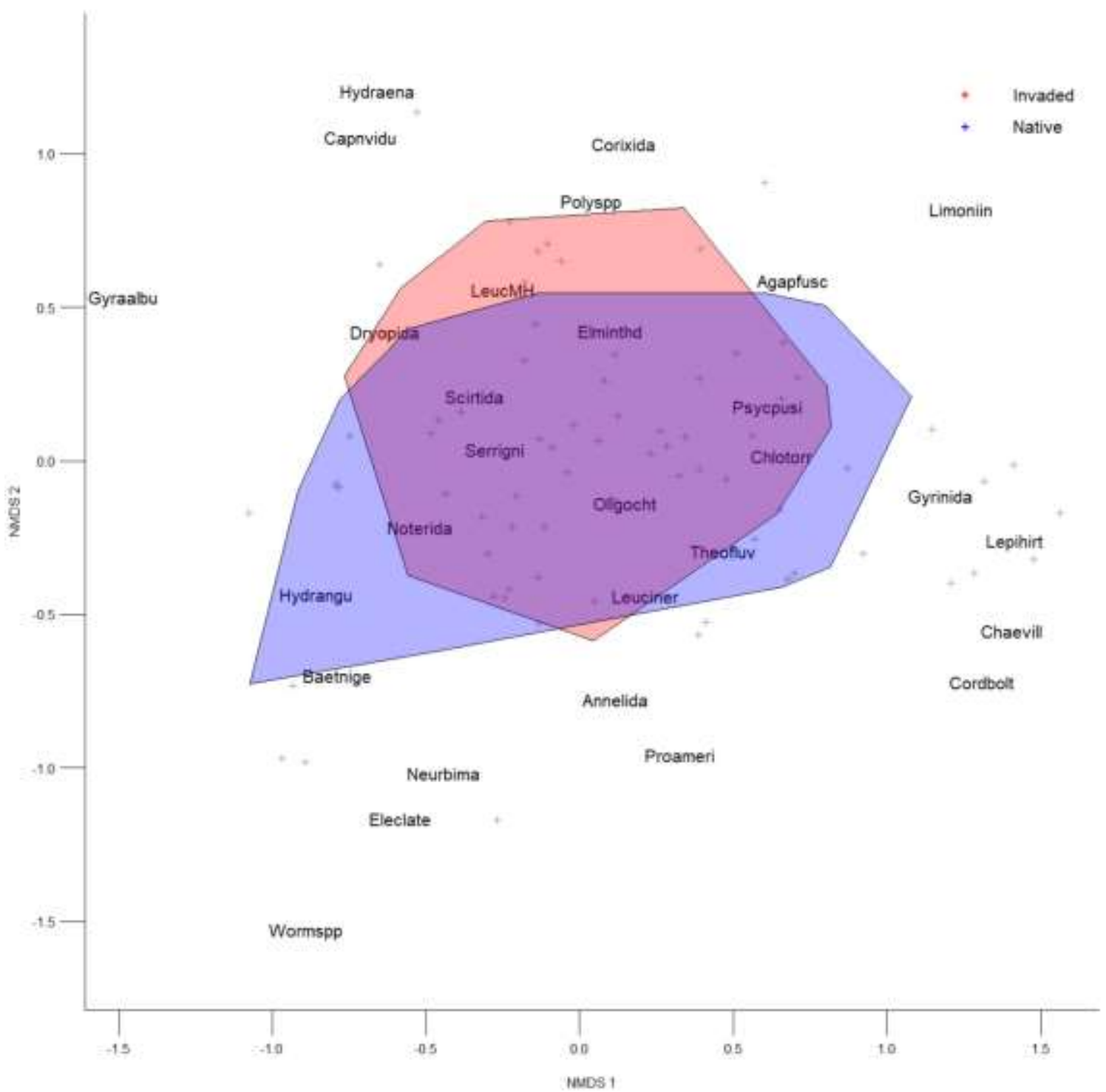


16 Figure S2. Non-metric multidimensional scaling ordination (NMDS) plot of macroinvertebrate species

17 composition, comparing invaded (red polygon) and uninvaded (blue polygon) sites in autumn across 24 riparian 18 sites (stress $=0.22)$

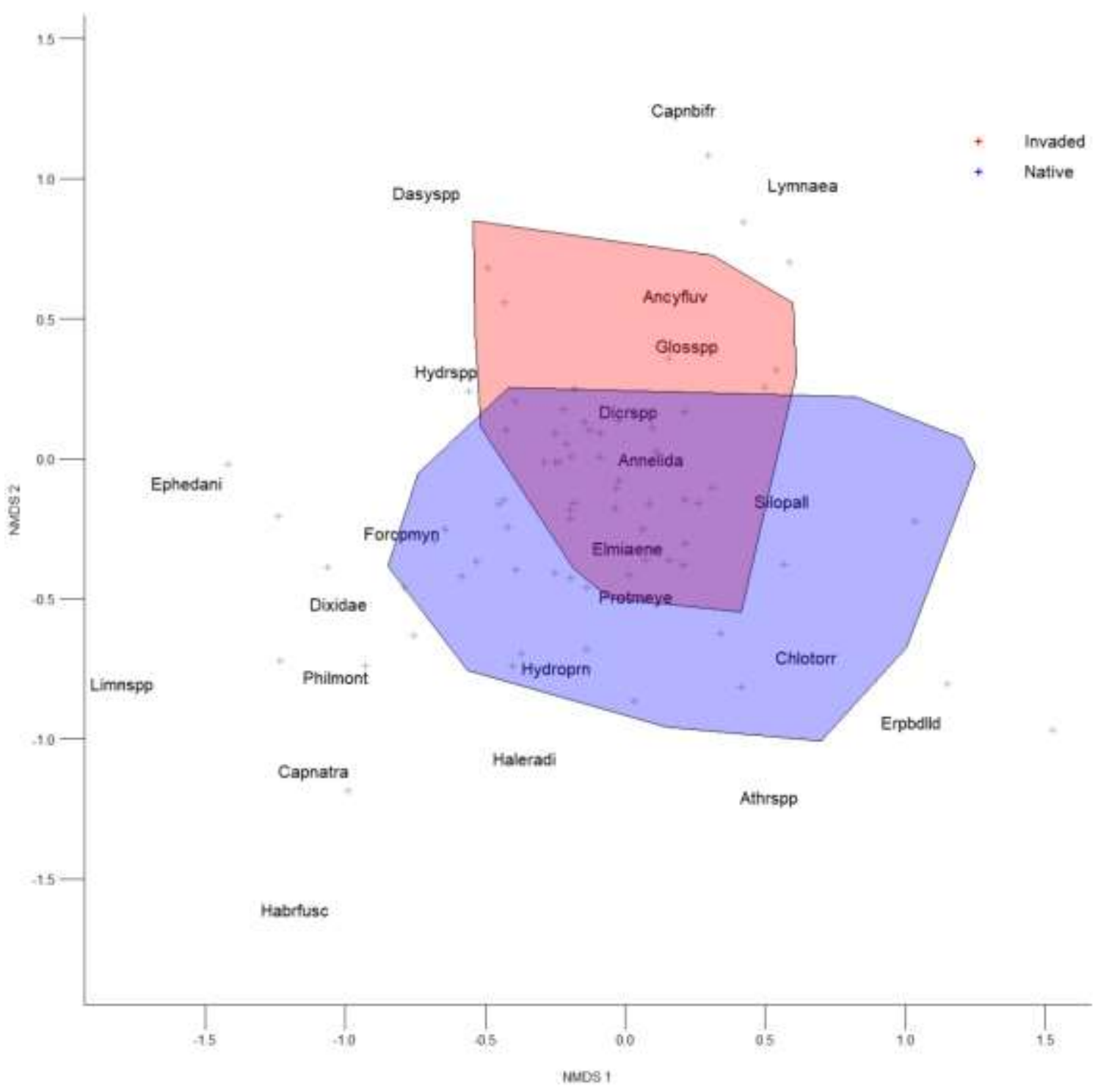

19 
20 Figure S3. Redundancy analysis (RDA) ordination of macroinvertebrate communities in autumn.

21 Environmental variables include conductivity $(\mathrm{S} / \mathrm{m})$ and invasive non-native plant cover (\%)

22

23

24

25

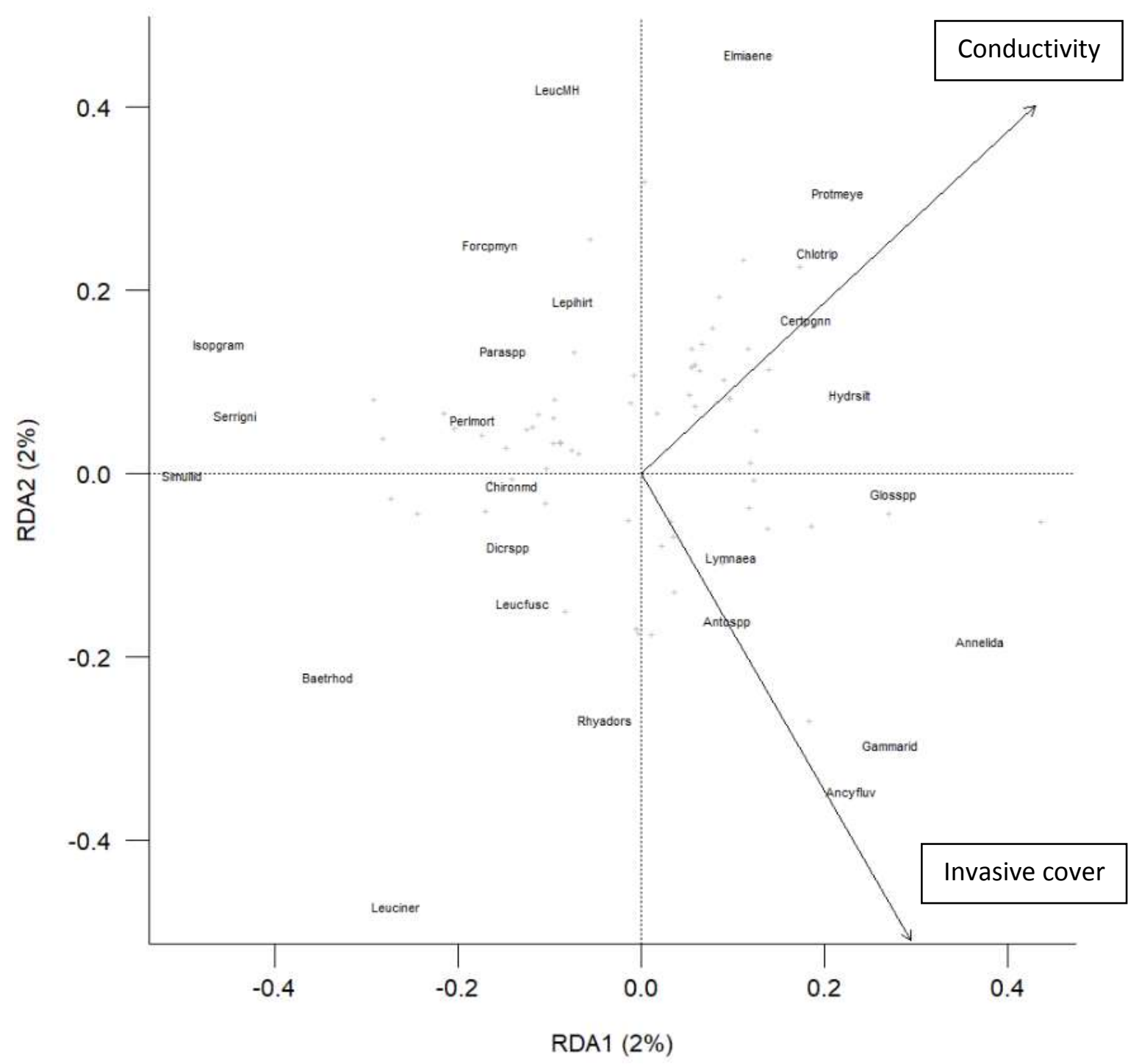

